\title{
Académie Royale des Sciences Coloniales
}

LE roi Baudouin a conféré à l'Institut royal colonial belge le titre d'Académie royale des Sciences coloniales à l'occasion du $25^{\mathrm{e}}$ anniversaire de la fondation de cette institution et en reconnaissance des services rendus par elle à la Belgique et à la Colonie. La commémoration de cet anniversaire a été marquée par une séance solennelle qui s'est déroulée le 27 octobre au Palais des Académies en présence du Roi. Le président de l'I.R.C.B., le Docteur Rodhain, retraça l'action personnelle du roi Albert dans le développement de la recherche scientifique au Congo, en particulier dans la domaine de la médecine, et il évoqua l'arrêté royal de septembre 1928 portant création de l'Institut royal colonial belge, dont il définit les buts. M. E.-J. Devroey, secrétaire général de l'Institut, retraça l'activité des trois sections de l'I.R.C.B. au cours des vingt-cinq années et énuméra l'imposante série des publications de l'Institut: le Bulletin des Séances, les trois séries de Mémoranda, la Biographie Coloniale Belge et l'Attas général du Congo. Il fit mention aussi du travail scientifique réalisé par les commissions de l'Institut et de la part prise par l'I.R.C.B. dans l'octroi des subsides à des savants s'occupant d'études entrant dans ses attributions. On peut remarquer que le Professeur Édouard de Jonghe, ancien Secrétaire Général de l'I.R.C.B., a été, jusqu'a sa mort, membre du Conseil Exécutif et Directeur Consultatif de l'Institut International Africain.

\section{Symposium on the Future of Customary Lan in Africa}

ON the initiative of the Afrika-Instituut, Leiden, an international Symposium on the future of customary law in Africa will be held at Amsterdam from 13 to Is April 1955. Belgian, British, Dutch, and French experts will participate, and a Portuguese and an American observer have been invited. The symposium will be concerned with both tropical and North Africa and will consider the ethnological as well as the juridical aspects of the subject. Some part of the discussions will be devoted to problems of Islamic law in Africa.

\section{Reproduction of Bibliographical Card Index}

OVER the past ten years the International African Institute has built up a bibliographical card index of books, reports, and articles relating to a wide range of African studies. The basic classification of the entries is regional, the regions being subdivided into territories; an introductory section, classified by subjects, telates to colonial territories, particularly Africa, in general. Each regional section is further classified under subject heads, e.g. Administration, Anthropology, Education, Linguistics, the anthropological and linguistic divisions being subdivided by tribes and languages. The card index comprises some 40,000 entries. It has been suggested that the card index should be reproduced and copies made available to libraries, research institutions, university departments, and other organizations specializing in African studies, and a grant from the Ford Foundation has now made it possible to finance the necessary preliminary work.

It is proposed that the reproduction of the existing card index should be followed by the issue of quarterly supplements based on the current bibliographies in this journal. Since it is to be a continuing bibliography, rather than a completed work, it might be most useful in the form of a card index, into which the supplementary entries could be inserted; on the other hand, considerations of cost and transport might make it advisable to issue the bibliography in the form of a series of volumes in which the entries will be arranged in such a way as to facilitate their use as the basis of a card index if desired.

Since this project will involve considerable labour and initial expense, it would be useful to know before it is set on foot how far it would receive the support of other organizations. 